\title{
Internal control, related party transactions and corporate value of enterprises directly controlled by Chinese central government
}

Yan Tong ${ }^{1 *}$, Mingzhu Wang ${ }^{2}$ and Feng $\mathrm{Xu}^{3}$

* Correspondence:
tongyan@bit.edu.cn
${ }^{1}$ School of Management and
Economics, Beijing Institute of
Technology, Beijing 100081, China
Full list of author information is
available at the end of the article

* Correspondence: tongyan@bit.edu.c Economics, Beijing Institute of Technology, Beijing 100081, China available at the end of the article

\begin{abstract}
State-owned enterprises (SOEs) play a crucial role in China's economy. Those directly controlled by the central government (CSOEs) take leading positions almost in all industries in China. In this paper, we analyse the impacts of internal control quality of CSOEs on related party transactions and corporate value of CSOEs after the Chinese government introduced regulatory changes and the split share structure reform. Current literature offers little empirical evidence in this area. The primary information collected from 167 questionnaires responded by 22 CSOEs is analysed using structural equation models. We find that internal controls of a higher quality reduce unfair related party transactions for private benefits at the cost of corporate value and hence increase the corporate value of CSOEs. However, the overall perception of the internal control quality of CSOEs is not satisfactory with a mean of 5.3174 based on a seven-point Likert scale. This indicates that effective implementation of internal control is critical for CSOEs after setting up regulations and systems.

Keywords: Internal control; Related party transactions; Corporate value; CSOEs
\end{abstract}

\section{Background}

The internal control of a good quality can reduce accrual and real earnings management and firms that disclose auditor's internal control report have lower level of earnings management (Fang and Jin 2011). However, we know little from the previous literature whether the quality of internal controls has any impact on related party transactions and corporate value. Such research question is of a great importance in the Chinese context. During the last decade, internal control systems have been established in most listed companies and some unlisted companies in China. Recently, theoretical and empirical studies on the quality of internal controls in the Chinese context emerge. However, due to the complicated situation and information unavailability, little direct evidence is reported for the effects of internal control on corporate value (Lin et al. 2007).

Previous studies in this area only analyse internal controls of listed firms in China. Our study focuses on state-owned enterprises directly controlled by Chinese central government (CSOEs) because they are distinct from listed firms. CSOEs have a common controlling shareholder - the government. Because of their powerful controlling shareholder, CSOEs have competitive advantages in almost all trades. CSOEs generally

(c) 2014 Tong et al.; licensee Springer. This is an open access article distributed under the terms of the Creative Commons Attribution License (http://creativecommons.org/licenses/by/2.0), which permits unrestricted use, distribution, and reproduction in any medium, provided the original work is properly cited. 
are large business groups with complicated group structures. Most of the CSOEs have one or more listed companies. Consequently, CSOEs are different from other listed firms in strategies, operations and internal controls. To overcome the data unavailability problem faced by other researchers in this area, we conducted a survey to all CSOEs in China and received 167 questionnaires (Additional file 1) responded by employees from 22 CSOEs. As far as we know, a survey is the only way to obtain the information on the efficiency of internal controls in CSOEs.

The primary agency relationship between shareholders and managements (Jensen and Meckling 1976; Ang et al. 2000; Singh and Davidson 2003; Zhong et al. 2010) has been studied thoroughly in Anglo-Saxon contexts. Different from these country contexts, agency problems amongst the controlling shareholders, institutional investors, individual investors ( $\mathrm{Li}$ et al. 2004; Yang 2006; Jian and Wong 2010) and members of business groups (Shao and Liu 2008; Xie and Wang 2010) are more critical in China. In particular, agency problems in CSOEs are complicated by issues like insider control (Zhong et al. 2010; Ma et al. 2012) and ownership concentration accompanied with an 'absence of the owner'(Liao and Fang 2005; Bai and Wu 2008). These may result in adverse economic consequences given the leading positions of CSOEs almost in all industries. Chinese regulators, therefore, pay particular attentions to the quality of internal controls of CSOEs.

Efficient internal control can, to some extent, prevent the self-interested behaviours resulting from agency problems in incomplete contracts, for example, unfair related party transactions, managerial opportunism and earnings management (Li et al. 2004; Meng and Zhang 2006; Rao et al. 2008). In this paper, we focus on the impact of internal control quality on related party transactions because such transactions can be managed by related parties and directly influence corporate value. According to FASB No. 57, related parties are defined to include three basic categories of individuals: board members, executives and principal owners (owners of more than $10 \%$ of voting interests of the enterprise). Considering the influence power of these stakeholders in CSOEs, related party transactions attract more attention from researchers and regulatory entities than unrelated party transactions. Fair related party transactions have arm-length prices and normal business processes, which efficiently fulfil underlying economic needs of the company (Gordon et al. 2004). However, unfair related party transactions under a weak governance system with agency conflicts are often used to transfer wealth for private benefits of related parties (Chen and Wang 2005; Cheung et al. 2009).

This paper offers twofold contributions to the literature. First, it demonstrates the relationship between internal control and related party transactions in CSOEs. The internal control is evidenced to be related to financial reporting (Doyle et al. 2007; Altamuro and Beatty 2010; Skaife et al. 2013), earnings quality (Fang and Jin 2011), risk and cost of capital (Ogneva et al. 2007; Dhaliwal et al. 2011) and management guidance (Feng et al. 2009). One neglected area of research is whether internal controls affect managerial incentives in related party transactions. Our paper provides empirical evidence that the quality of internal controls in CSOEs constrains unfair related party transactions. Second, our paper evaluates the efficiency of internal control and tests the mediation effect in CSOEs based on insiders' judgments. It is normally difficult or even impossible for outsiders to evaluate the efficiency of internal control of CSOEs. As such, evaluations from outsiders normally base on the outcomes such as related party 
transactions and corporate value, which raise concerns on endogeneity. Our study starts from the insiders' evaluation to the internal control of their employers and then analyses the impact of internal control on related party transitions and corporate value.

The remainder of the paper is organized as follows. The 'Methods' section reviews relevant literature, develops our hypothesis in the context of the regulation background and introduces the data and models. The 'Results and discussion' section reports the results. The 'Conclusions' section summarizes the findings and concludes the paper.

\section{Methods}

Literature review and hypothesis development

Internal controls and economic consequences

According to the Treadway Commission, the term 'internal control' is related to controls over financial reporting, operational tasks such as product quality assurance and plant maintenance (NCFFR 1987). The Sarbanes-Oxley Act of 2002 (SOX) requires the implementation of many new rules and procedures (Ge and McVay 2005). Section 404 especially requires that managers maintain adequate internal controls over financial reporting and provide an auditor-attested assessment of their effectiveness in the annual report (Ogneva et al. 2007). Since 2002, SOX and other regulations have been issued and implemented to ensure the internal control qualify of firms. There has been a surge of research on the economic consequences of internal controls. Due to the limited public information on the internal control of firms, research in this area often focuses on internal control deficiencies (Bedard and Graham 2011). Material weakness in internal control tend to be related to deficient revenue recognition policies, lack of segregation duties, deficiencies in the period-end reporting process and accounting policies (Ge and McVay 2005). Weak internal controls are associated with lower accrual quality (Doyle et al. 2007; Ashbaugh-Skaife et al. 2008). Because of the agency problem, the profitability of insider trading is significantly greater in firms disclosing material weaknesses in internal control relative to firms with effective control (Skaife et al. 2013). Weak internal controls are also found to be associated with the cost of debts. On average, a firm's credit spread on its publicly traded debt marginally increases if it discloses a material weakness (Dhaliwal et al. 2011). Kim et al. (2011) further find that the loan spread and the loan rates are higher for internal control-weak (ICW) firms than for non-ICW firms, after controlling for other known determinants of loan contract terms. If the internal controls remain ineffective, the less accurate guidance persists but is mitigated if the internal control problems are remediated (Feng et al. 2009). The management forecast errors are larger when the internal control problems are most likely to affect interim numbers and thus guidance. The impact of ineffective internal controls on forecast accuracy is three times larger when the weakness relates to revenues or the cost of goods sold (Feng et al. 2009). In summary, internal control quality has economically significant effects on accounting policies, accrual quality, cost of debts and management guidance.

\section{Regulations related to the corporate internal control in China}

Internal controls have not been mandatorily required to be implemented in Chinese listed firms until 2006 due to a series of regulatory changes. 
First, China experienced the split share structure reform (the Reform hereafter) in 2006. After the Reform, the China Security Regulatory Committee (CSRC hereafter) issued 'Measures for the Administration of Initial Public Offering and Listing of Stocks', which requires internal controls for listed companies for the first time. According to this regulation, companies in the initial public offering (IPO) process must have a sound and effective internal control system that should guarantee the reliability of financial reports, compliance with laws and regulations, efficiency and effectiveness of business operations. The efficiency of the internal control system should be assessed by public certified accounting with an assurance report on internal control. This regulation issued by the CSRC should be complied by all the IPO firms no matter whether they are SOEs or non-SOEs.

The second regulatory change in 2006 was 'Comprehensive Risk Management Guidance for CSOEs' (the Guidance hereafter) issued by the State-owned Assets Supervision and Administration Commission of the State Council (SASAC hereafter). SASAC performs investor's responsibilities for CSOEs, i.e. supervising the preservation and increment of CSOEs' corporate value as well as managing the state-owned assets of the enterprises by regulations. The Guidance for CSOEs requires that their internal control system should help risk management and include all the major business processes, such as strategy, investment, marketing, accounting, producing, etc.

Third, the Ministry of Finance, CSRC and other three commissions issued 'The Basic Internal Control Norms for Enterprises' in 2008 and 'The Enterprise Internal Control Guidelines' in 2010 (the Guidelines hereafter). Listed companies in Shanghai and Shenzhen stock exchanges have to comply with these two sets of regulations from 2012. Unlisted firms of large and median sizes are also encouraged to comply with the Guidelines. Similar to the internal control objectives in CSRC's regulations, five components should be structured in the internal control system of a firm, including control environment, risk assessments, information and communications, control activities and monitoring.

The internal control quality of listed firms and CSOEs is regulated by the government using the above-mentioned Guidance and Guidelines. Because most of the CSOEs have one or more listed companies, CSOEs must abide both the Guidance and the Guidelines by preparing internal control reports for the Ministry of Finance and risk management reports for SASAC. Some recent evidence shows that the quality of the internal control of CSOEs is different from that of other listed firms. For instance, the internal control of CSOEs is more efficient than that of other listed firms (Cheng and Wang 2008). However, Leng and Ding (2011) find that the disclosure of internal control is negatively related to the proportion of state ownership. Since SOEs including CSOEs tend not to disclose information on internal controls to the public, it remains unclear in the literature the effect of internal controls of CSOEs.

\section{Internal control and related party transactions}

Through related party transactions, cash and profits can be diverted away from firms either to controlling shareholders or to assist troubled firms within the group (Jian and Wong 2004). For example, controlling shareholders loot their own firms during the emerging market crisis of 1997 to 1998. Firms in developed markets also use related party transactions to transfer assets and profits out of firms for the benefit of 
controlling shareholders (Johnson et al. 2000). Related party transactions have also been under the limelight in a number of recent US and European accounting scandals, such as transactions between Enron and its special-purpose entities. Related party transaction is prevalent in China due to the corporate structures, economic institutions and the legal system. According to the 2001 annual reports of Chinese listed firms, 90\% of them are involved in different degrees of related party transactions (Jian and Wong 2004). State-owned groups are usually formed out of a number of related large-scale SOEs. Because of their planned economy tradition, SOEs tend to have more related party transactions within the group than non-SOEs. As such, related party transactions are more prevalent in CSOEs than in other listed firms.

By manipulating transfer prices, economic resources can be transferred between different stakeholders, resulting in gains to some and losses to others. Related party transaction may distort financial statements leading to greater information asymmetry and a general erosion of investors' confidence in the firm. To the best of our knowledge, there is no empirical research on whether and how internal control has any impact on related party transactions, especially in CSOEs, although some papers study the relationship between corporate governance and related party transactions. Corporate governance has direct effects on related party transactions (Kohlbeck and Mayhew 2004), and weaker corporate governance mechanisms are associated with more and higher dollar amounts of related party transactions (Gordon et al. 2004). The quality of corporate governance is important in deterring the use of manipulated transfer prices in relatedparty sales transactions (Lo et al. 2010).

According to the contract theory and the agency theory (Jensen and Meckling 1976), various stakeholders take part in corporate contracts with different interests and asymmetric information (Grossman and Hart 1986). Related party transactions can be used by controlling shareholders and/or top executives for their own private benefits at the cost of deteriorating corporate value. Internal control is designed to help the organization accomplish specific goals, one of which is improving operational outcomes to achieve the strategic objective. A healthy and effective internal control system can prevent insiders tunnelling the firm (Kohlbeck and Mayhew 2004). Of course, not all the related party transactions are value-destroying. Fair related party transactions are efficient and cost-saving. Due to information asymmetry, outsiders cannot distinguish the quality of related party transactions. Companies that really need to engage in fair related party transactions may suffer from stakeholders' criticism. The most important stakeholder of CSOEs is SASAC because of its influence on important decisions of CSOEs including related party transactions despite the fact that SASAC cannot make any direct influence through multiple agency relationships. CSOEs may build a better reputation by adopting and disclosing a good internal control system designed to prevent tunnelling or manipulating by related party transactions. This leads to our hypothesis 1 :

Hypothesis 1: effective internal control in CSOEs can enhance the fairness of related party transactions.

\section{Related party transactions and corporate value}

Related party transactions arise as efficient contracting arrangements in situations involving incomplete information (Ryngaert and Thomas 2007). Related party transactions 
motivated by shared benefits are fair, efficient and convenient, which could help increase the corporate value (Zhou and Zhang 2008). But under a weak governance, related party transactions are often viewed as unfair and being detrimental to outside shareholders (Chen and Wang 2005; Cheung et al. 2009). Both tunnelling (Johnson et al. 2000; Rao et al. 2008; Berkman et al. 2009) and propping (Friedman et al. 2003; Jian and Wong 2010) are controlled by insiders - controlling shareholders and top executives. Negative cumulative abnormal returns (CAR) have been found for companies that disclose related party transactions (Stouraitis et al. 2006). Tobin's $Q$ and market-to-book value are significantly lower for firms undertaking potentially expropriating transactions (Lei and Song 2011). Similar evidences also have been found in listed companies in Shanghai and Shenzhen stock exchanges based on a pre-Reform sample (Li et al. 2004).

Before the Reform, controlling shareholders' stocks were non-tradable on stock market. As a result, controlling shareholders were indifferent to the stock price but have motivations in getting private benefits via unfair related party transactions (Meng and Zhang 2006). After the Reform, stocks hold by controlling shareholders become tradable, which may reduce their incentives in exploiting minority shareholders via unfair related party transactions.

Although CSOEs are not wholly listed, most of them have one or more listed subsidiaries. According to 'The Guiding Opinions about Promoting the Adjustment of Stateowned Capital and the Reorganization of State-owned Enterprises' issued by SASAC, CSOEs are encouraged to become wholly listed or to allocate assets of a high quality into their listed companies. Furthermore, CSOEs are required to follow both the Guidelines on internal control and the Guidance for risk management after the Reform. Under such changes in regulatory environment, CSOEs are expected to manage related party transactions more carefully than before.

Considering these regulatory and economic factors, we can safely infer that related party transactions influence corporate value as it determines controlling shareholders' support to listed companies after the Reform. Therefore, we construct hypothesis 2:

Hypothesis 2: in an effective internal control system, related party transactions will be beneficial to CSOEs' corporate value.

\section{Data and models}

We collect data from a survey to CSOEs based on two reasons. First, the related data at the group level are not available. Before whole listing of the CSOEs, they only need to disclose the information on listed companies within the groups. Second, the internal control quality is very difficult to be evaluated exactly by outsiders. Various proxies of internal control quality have been used in academic studies and practices, such as the disclosure of material weaknesses (Ge and McVay 2005), auditor's internal control report (Lin and Rao 2009) and indices based on a matrix of various ratios (Wang et al. 2011). No matter what measures to be used, the internal control is not the same as financial reporting with quantity contents and standard forms. Considering information unavailability from the public disclosures, insiders' opinions based on an anonymous promise are better proxies than outsiders' conjectures and deductions.

In addition, the information related to the internal control of CSOEs is not disclosed to the public because of their sensitive ownership structure. A survey is the only feasible approach for us to gather the data for our research. Although the data collected via 
questionnaires are commonly criticized for their subjectivity, we use several means to ensure that the results of our survey are objective and reliable. Firstly, the survey was sent to all listed CSOEs to make the data selection process to be random rather than biased. Secondly, we sent the questionnaires to employees at different positions in CSOEs, ranging from executive managers and financial managers to other staffs in financial departments. This further reduces the self-selection bias in our data collection and enhances the objectiveness in the responses. In empirical analyses, we also test the reliability and validity of the collected data.

We design the questionnaire through a trail survey. Before the formal investigation, we arranged a trail survey participated by seven professors, five experts from four CSOEs and 34 MBA students. According to the results from the tests, we correct some expressions, delete some items and finalize the questionnaire for the formal investigation. In addition to participants' basic information like ages and positions, we design three major parts in the finalized questionnaire by using a seven-point Likert scale in the questionnaire. The first part is an overall evaluation including 11 questions about the internal control quality of the CSOEs the participant is working for. The second part includes 5 components of internal control with at least 10 questions for every component. The third part is for the relationships between internal control quality and business operations as well as between related party transactions and corporate value, to which 18 questions are related. The participants are employees of CSOEs, and they are required to score each question based on their own perception and judgment for their companies.

With the support of SASAC, we sent out 250 questionnaires to all listed CSOEs and received 167 valid responses, including those from China Petrochemical Corporation (Sinopec), China National Petroleum Corporation (CNPC) and other 20 CSOEs. The response rate is $66.8 \%$. Majority of the participants (95\%) are employees from accounting or finance departments of CSOEs, which ensures that the participants have professional knowledge to evaluate internal control, related party transactions and corporate value.

Definitions of main variables are given in Table 1 with the numbers of supporting questions (items).

Descriptive analyses to the main variables are reported in Table 2. According to Table 2, the means of internal control and its five components are all slightly higher than 5 , indicating that the participants of the survey general perceive the internal control system as useful. Amongst the five components of internal control, IAC has the

Table 1 Variable definitions

\begin{tabular}{llc}
\hline Variables & Definitions & Number of supporting questions (items) \\
\hline ICQ & Internal control quality is good & 11 \\
CE & Control environment is good & 14 \\
RA & Risk assessment is reasonable & 9 \\
IAC & Information and communication are quick & 11 \\
CA & Control activities are effective & 13 \\
M & Monitoring effect is good & 10 \\
RPT & Fairness of related party transactions is enhanced & 7 \\
CV & Corporate value is increased & 11 \\
\hline
\end{tabular}


Table 2 Descriptive statistics

\begin{tabular}{lcccc}
\hline & Mean & Standard deviation & Minimum & Maximum \\
\hline ICQ & 5.3174 & 1.2276 & 2 & 7 \\
CE & 5.4731 & 1.1021 & 2 & 7 \\
RA & 5.3293 & 1.1794 & 2 & 7 \\
IAC & 5.7305 & 0.9659 & 3 & 7 \\
CA & 5.3832 & 1.1603 & 1 & 7 \\
M & 5.4252 & 1.1994 & 2 & 7 \\
RPT & 5.4551 & 1.0511 & 2 & 7 \\
CV & 5.5928 & 0.9949 & 2 & 7 \\
\hline
\end{tabular}

highest mean of 5.7305 and its minimum value is 3, which is also greater than the minimums of other variables. These show that the participants of the survey perceive the information and communication to be efficient within the CSOEs. RA has the lowest mean of 5.3293, indicating that the risk assessment in CSOEs is not as satisfactory as other components of internal control. Besides, the means of internal control is low than the average of the means of the five components whereas the standard deviation of internal control is 1.2276, which is higher than the standard deviations of all the five components. These indicate that participants of the survey have more conservative and distinct perceptions of the internal control system due to its complexity. The relatively high means of RPT (5.4551) and CV (5.5928) indicate that participants of the survey generally agree that a better internal control quality reduces related party transactions and enhances the corporate value.

\section{Results and discussion}

The ratio of our sample size to the number of free parameters in a structural equation model is 5 to 1 as recommended by Bentler and Chou (1987). Because each part of internal control quality has around 10 questions while the effective sample number is 168 , we try to reduce the dimension to yield more powerful results.

\section{Principal component analysis}

In multiple regressions, using a large number of independent variables may cause the dependent variable to be regressed against a large number of covariates. Retaining all covariates will likely lead to severe multicollinearity or non-identifiability of regression coefficients. Variable selection techniques are not often very effective, and we are interested in including information from all of the covariates. Based on these considerations, we conducted principal component analysis. Principal component analysis enables us to find a small set of linear combinations of the covariates, which are uncorrelated with each other, to avoid the multicollinearity problem. It also ensures that the linear combinations chosen in our regression design have the maximal variance.

We use a scree plot in principal component analysis. A scree plot identifies the principal components which are shown as the turning points in the plot. The principal components are sorted in decreasing order of variance, so the most important principal component is always listed first. The cumulative variance explained by the identified principal components should reach above $85 \%$. Then we get the structural equation model with the new components derived from the original items in Figure 1. Figure 1 


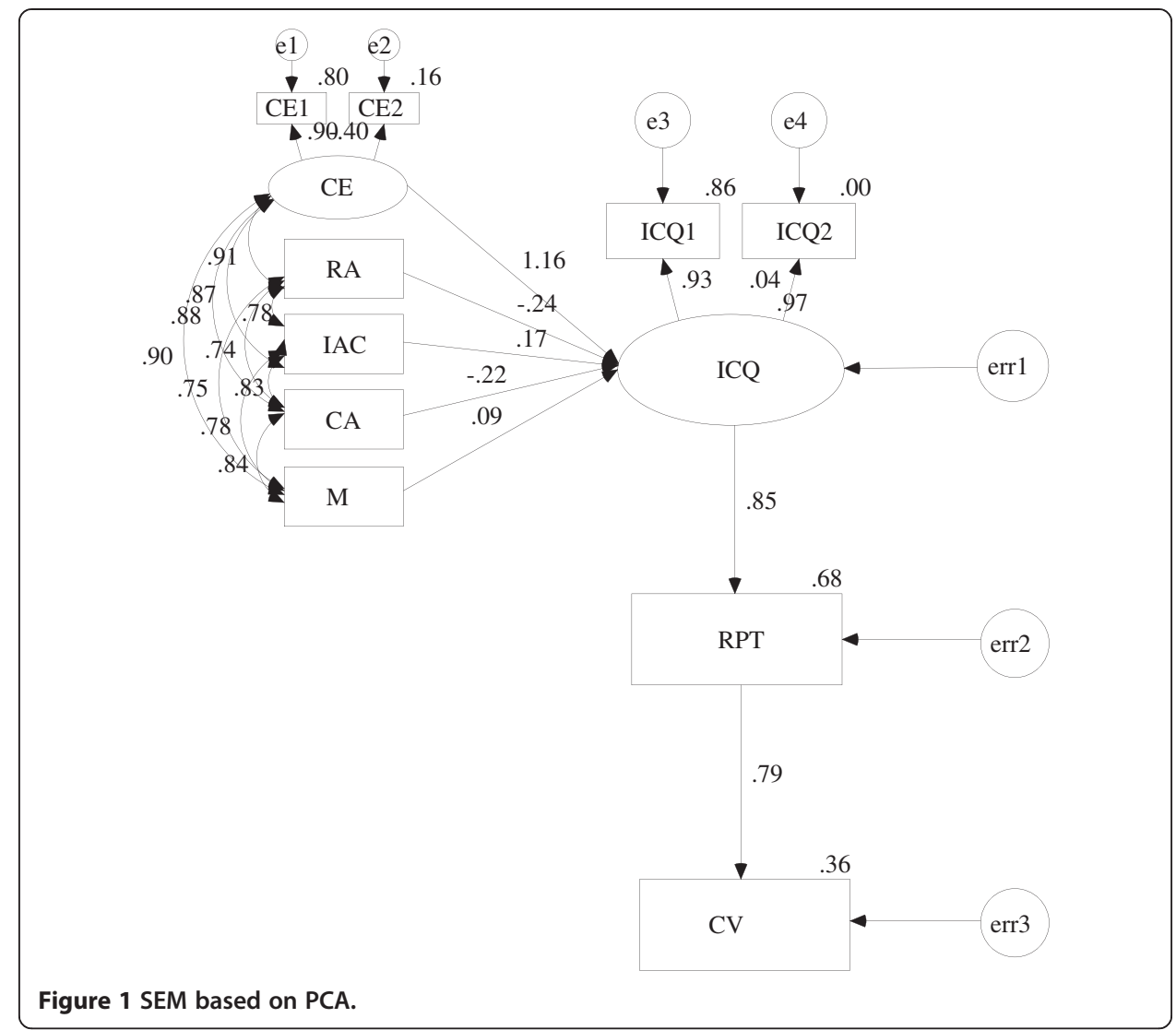

shows that all the dimensions covered in the questionnaire have been consolidated into five components of internal control, related party transactions and corporate value in the structural equation model (SEM).

Table 3 reports the fit criteria of the SEM. Almost all the absolute fit indices are at satisfactory levels. According to Table 3, the $p$ value of $\chi^{2}$ of the structural equation model is 0.062 , which satisfies the criterion that the $p$ value of $\chi^{2}$ should be greater than 0.05. The goodness-of-fit index (GFI) and adjusted goodness-of-fit index (AGFI) also satisfy the criterion of being greater than 0.9. Although root-mean-square error of approximation (RMSEA) does not satisfy the criterion, its value is very close to the acceptable standard. The means of all comparative fit indices are greater than 0.9 , which satisfy the criteria. In addition, all three parsimonious fit indices, i.e. parsimonious goodness-of-fit index (PGFI), parsimonious normed fit index (PNFI) and normed chisquare $(\mathrm{NC})$, reach the acceptable standards. Overall, the fit criteria of the structural equation model are satisfied.

We can test the relationship amongst internal control quality, related party transactions and corporate value based on this model with reasonable confidence. The results are shown in Table 4. According to Table 4, the C.R. (Critical Ratio) value of paths 'ICQ $\rightarrow$ RPT' and 'RPT $\rightarrow$ CV'is greater than 1.96 , which passed the reliability test. The coefficients of both paths are positive $(0.846,0.794)$ at the $5 \%$ significance level. The coefficient of the path ICQ $\rightarrow \mathrm{RPT}$ is significantly positive, indicating that a better internal control quality enhances the fairness of party related transactions. This finding supports our hypothesis 1 . The positive coefficient of the path RPT $\rightarrow \mathrm{CV}$ shows that 
Table 3 Fit indices in the structural equation model based on PCA

\begin{tabular}{lcc}
\hline Measures & Standards & Values \\
\hline Absolute fit indices & $x^{2} p>0.05$ & $34.204(p=0.062)$ \\
$X^{2}$ & $>0.90$ & 0.961 \\
GFI & $>0.90$ & 0.906 \\
AGFI & $<0.05$ & 0.054 \\
RMSEA & & \\
Comparative fit indices & $>0.90$ & 0.976 \\
NFI & $>0.90$ & 0.954 \\
RFI & $>0.90$ & 0.992 \\
IFI & $>0.90$ & 0.984 \\
TLI & $>0.90$ & 0.992 \\
CFI & & \\
Parsimonious fit indices & $>0.05$ & 0.402 \\
PGFI & $>0.05$ & 0.499 \\
PNFI & $1<N C<3$ & 1.487 \\
NC & & \\
\hline
\end{tabular}

the improved fairness of related party transactions increases corporate value. Therefore, the prediction of our hypothesis 2 is also supported.

\section{Mean value}

We use the mean value of the items in a given part to reduce dimensions as a robust test for the empirical analyses conducted in the 'Principal component analysis' section. The structural equation model using mean values is illustrated in Figure 2. The test results are reported in Table 5. According to Figure 2 and Table 5, the findings remain consistent with those from Figure 1 and Table 3 . All the absolute fit indices are at satisfactory levels. According to Table 5 , the $p$ value of the $\chi^{2}$ of the structural equation model is 0.055 , which is greater than the required $p$ value of 0.05 . GFI and AGFI also satisfy the criterion of being greater than 0.9. Similar to the finding in Table 3, RMSEA does not satisfy the criterion, but its value is very close to the acceptable standard. The

Table 4 Path estimates in the structural equation model based on PCA

\begin{tabular}{lccc}
\hline & Estimate & C.R. & $\boldsymbol{p}$ value \\
\hline $\mathrm{CE} \rightarrow \mathrm{ICQ}$ & 1.158 & & \\
$\mathrm{RA} \rightarrow \mathrm{ICQ}$ & -0.245 & -2.7 & 0.101 \\
$\mathrm{IAC} \rightarrow \mathrm{ICQ}$ & 0.168 & 1.642 & $*$ \\
$\mathrm{CA} \rightarrow \mathrm{ICQ}$ & -0.221 & -1.911 & 0.377 \\
$\mathrm{M} \rightarrow \mathrm{ICQ}$ & 0.095 & 0.884 & $*$ *** \\
$\mathrm{ICQ} \rightarrow \mathrm{RPT}$ & 0.846 & & \\
$\mathrm{CE} \rightarrow \mathrm{CE} 1$ & 0.896 & -5.408 & $*$ ** \\
$\mathrm{CE} \rightarrow \mathrm{CE} 2$ & -0.399 & & \\
$\mathrm{ICQ} \rightarrow \mathrm{ICQ} 1$ & 0.926 & 0.465 & 0.642 \\
$\mathrm{ICQ} \rightarrow \mathrm{ICQ} 2$ & 0.037 & 10.698 & $* * *$ \\
$\mathrm{RPT} \rightarrow \mathrm{CV}$ & 0.794 & &
\end{tabular}




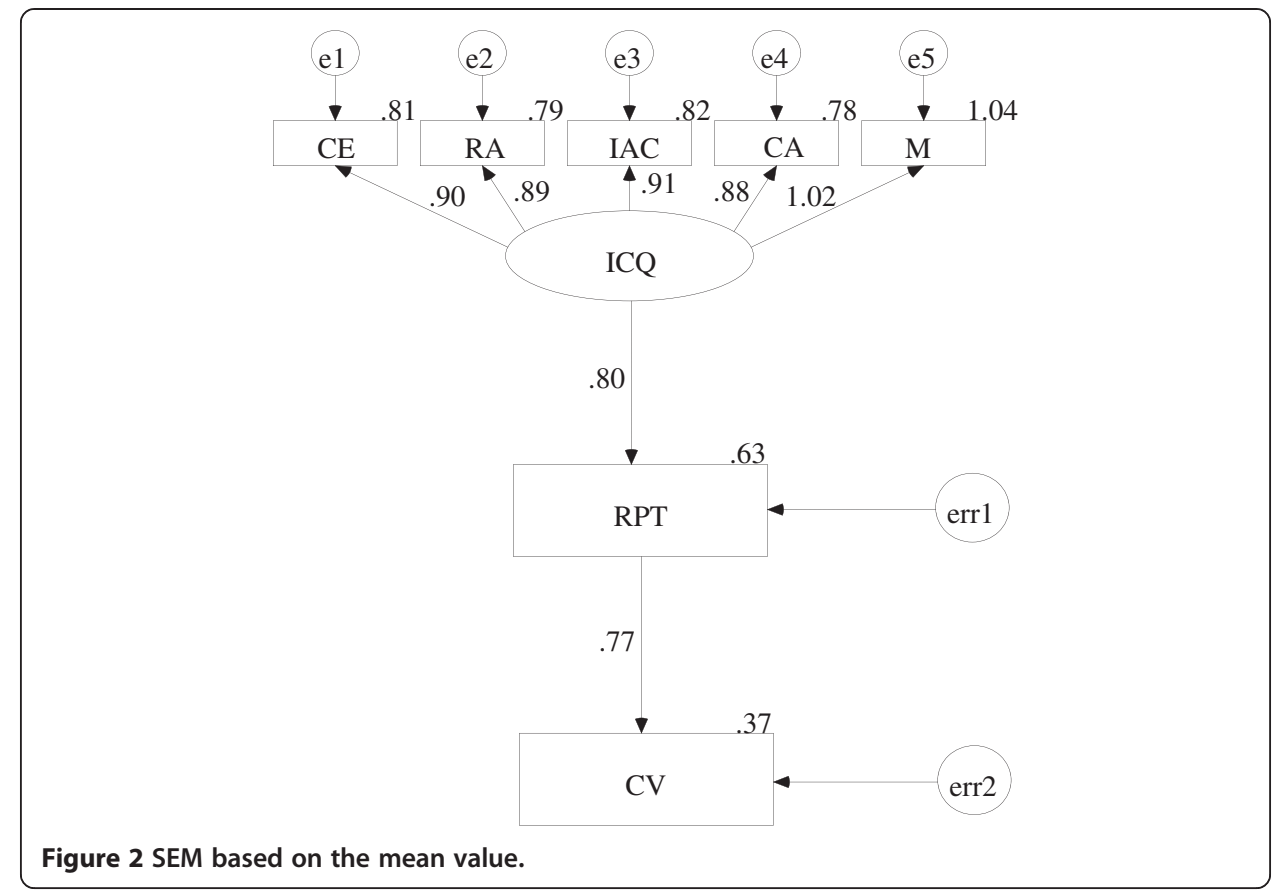

means of comparative fit indices are all greater than 0.9, which are satisfactory. All three parsimonious fit indices, i.e. PGFI, PNFI and NC, also reach the acceptable standards. These prove that the fit criteria of the structural equation model are satisfied.

We test the relationship amongst internal control quality, related party transactions and corporate value based on this model with reasonable confidence. According to the results shown in Table 6, all the variables passed the validity test and all the paths in the structural equation model based on mean values are significantly positive at the $5 \%$ level. Especially, the estimates of ICQ to RPT and PRT to CV are 0.797 and 0.771, respectively. These findings are consistent with those reported in Table 4. Both the

Table $\mathbf{5}$ Fit indices in the structural equation model based on the mean value

\begin{tabular}{lcc}
\hline Measures & Standards & Values \\
\hline Absolute fit indices & $x^{2} p>0.05$ & $18.006(p=0.055)$ \\
$X^{2}$ & $>0.90$ & 0.916 \\
GFI & $>0.90$ & 0.970 \\
AGFI & $<0.05$ & 0.069 \\
RMSEA & & \\
Comparative fit indices & $>0.90$ & 0.989 \\
NFI & $>0.90$ & 0.977 \\
RFI & $>0.90$ & 0.995 \\
IFI & $>0.90$ & 0.990 \\
TLI & $>0.90$ & 0.995 \\
CFI & & \\
Parsimonious fit indices & $>0.05$ & 0.346 \\
PGFI & $>0.05$ & 0.471 \\
PNFI & $1<$ NC $<3$ & 1.801 \\
NC & & \\
\hline
\end{tabular}


Table 6 Path estimates in the structural equation model based on the mean value

\begin{tabular}{lccc}
\hline & Estimate & C.R. & $p$ value \\
\hline $\mathrm{ICQ} \rightarrow \mathrm{RPT}$ & 0.797 & 14.816 & $* * *$ \\
$\mathrm{RPT} \rightarrow \mathrm{CV}$ & 0.771 & 10.369 & \\
$\mathrm{ICQ} \rightarrow \mathrm{CE}$ & 0.900 & & $* * *$ \\
$\mathrm{ICQ} \rightarrow \mathrm{RA}$ & 0.889 & 18.802 & $* * *$ \\
$\mathrm{ICQ} \rightarrow \mathrm{IAC}$ & 0.907 & 19.862 & $*{ }^{*}$ \\
$\mathrm{ICQ} \rightarrow \mathrm{CA}$ & 0.884 & 18.489 & $* * *$ \\
$\mathrm{ICQ} \rightarrow \mathrm{M}$ & 1.020 & 29.294 & $*$ \\
\hline
\end{tabular}

*** indicate significance levels at $10 \%$ and $1 \%$, respectively.

coefficients of the paths ICQ $\rightarrow \mathrm{RPT}$ and $\mathrm{RPT} \rightarrow \mathrm{CV}$ are positive, indicating that a better internal control quality enhances the fairness of the related party transactions, which increases the corporate value. As such, the predictions of our hypothesis 1 and hypothesis 2 are supported by the results reported in Table 6.

\section{Conclusions}

There is a recent surge of academic interest in internal control quality and its effects on different types of organizations. For example, causes and consequences of internal control problems have been analysed for non-profit organizations (Petrovits et al. 2011). Most studies investigate the internal control quality of listed firms because of their superior disclosures on internal control issues than other types of organizations. Previous studies find that the quality of internal controls is associated with the accounting policies (Ge and McVay 2005), earnings quality (Doyle et al. 2007; Ashbaugh-Skaife et al. 2008), cost of debts (Dhaliwal et al. 2011; Kim et al. 2011) and management forecasts (Feng et al. 2009) of the firm. However, existing literature provides little evidence on the effects of the internal control quality on the related party transaction and corporate value. Our study contributes to the literature by analysing the effects of the internal control quality of a special type of organization, i.e. CSOEs, which are business groups fully controlled by Chinese central government. In China, the internal control quality of CSOEs is particularly regulated by the government in the Guidance, and SOEs have more related party transactions than non-SOEs. We provide evidence that the quality of internal controls of CSOEs enhances the fairness of related party transactions and corporate value.

We gather the data through a survey to CSOEs and analyse the primary data using the structural equation model. Based on the contract theory, we use related party transactions as the mediator between internal control quality and corporate value. We hypothesize that a better internal control quality in CSOEs can enhance the fairness of related party transactions, which leads to an increased corporate value, which are both supported by the empirical evidence in our study. The results remain robust even if we use the mean values of variables in the structural equation model.

Our survey also offers a number of practical implications. The participants in the survey are not very satisfied with the quality of internal controls in their companies, and we could expect more improvements in the future. The weakest links in internal control systems are risk management and control activities according to the survey results, which are difficult to be implemented effectively in such large business groups as 
CSOEs. Managers of CSOEs should pay more attention to these elements of their internal control system.

The survey helps us to get insiders' opinions on the internal control of CSOEs that are not available from public information. Findings in this study enhance our understanding of whether and how the quality of internal control has any impact on related party transactions and corporate value. We contribute to the existing academic literature by demonstrating these relationships in CSOEs that take leading positions almost in all industries in China. Our findings for CSOEs as leading SOEs provide meaningful implications to other SOEs, which pave an avenue for future research. For example, we may further compare the internal controls of CSOEs, SOEs and non-SOEs. Such comparisons would be interesting especially in the context of Chinese capital market. Furthermore, this study provides implications for future regulatory changes, in China and elsewhere, to improve the internal control and to constrain manipulations in related party transactions.

\title{
Additional file
}

Additional file 1: Sample questionnaire.

\begin{abstract}
Abbreviations
CNPC: China National Petroleum Corporation; CSOEs: state-owned enterprises directly controlled by Chinese central government; CSRC: China Security Regulatory Committee; SASAC: State-owned Assets Supervision and Administration Commission of the State Council; Sinopec: China Petrochemical Corporation; SOX: Sarbanes-Oxley Act of 2002; the Guidance: 'Comprehensive Risk Management Guidance for CSOEs' issued by SASAC in 2006; the Guidelines: The Basic Internal Control Norms for Enterprises' (2008) and 'The Enterprise Internal Control Guidelines' (2010) issued by the Ministry of Finance, CSRC and other three commissions; the Reform: the split share structure reform of Chinese stock markets.
\end{abstract}

Competing interests

The authors declare that they have no competing interests.

Authors' contributions

YT designed the study, collected the survey data and drafted the manuscript. MW participated in the study design and drafted the manuscript. FX performed the statistical analyses. All authors have read and approved the final manuscript.

\section{Acknowledgements}

This study has been financially sponsored by the National Natural Science Foundation of China (No. 71372015, No. 70902012), the China Scholarship Council ([2010]3009), the Beijing Municipal Talents Project (No. 2012D009011000005) and the Basic Research Funds of Beijing Institute of Technology (No. 20122142010).

\section{Author details}

${ }^{1}$ School of Management and Economics, Beijing Institute of Technology, Beijing 100081, China. ${ }^{2}$ Department of Management, King's College London, London SE1 9NH, UK. ${ }^{3}$ China Development Bank, 18 Fuxingmennei Street, Xicheng District, Beijing 100031, China.

Received: 7 August 2013 Accepted: 21 March 2014

Published: 15 May 2014

\section{References}

Altamuro J, Beatty A (2010) How does internal control regulation affect financial reporting? J Account Econ 49:58-74 Ang J, Cole R, Lin J (2000) Agency costs and ownership structure. J Financ 55:81-106

Ashbaugh-Skaife H, Collins DW, Kinney WR Jr, LaFong R (2008) The effect of SOX internal control deficiencies and their remediation on accrual quality. Account Rev 83(1):217-250

Bai YX, Wu LS (2008) The impact of takeovers and change of ultimate control. J Financ Res 6:130-143, In Chinese

Bedard JC, Graham L (2011) Detection and severity classifications of Sarbanes-Oxley Section 404 internal control deficiencies. Account Rev 86(3):825-855

Bentler PM, Chou CP (1987) Practical issues in structural modeling. Sociol Methods Res 16(1):78-117

Berkman H, Cole RA, Fu LJ (2009) Expropriation through loan guarantees to related parties: evidence from China. J Bank Financ 33(1):141-156

Chen X, Wang K (2005) Related party transactions, corporate governance and state ownership reform. Econ Res J 4:77-128, In Chinese

Cheng X, Wang H (2008) Corporate governance on the effectiveness of internal control. Auditing Research 4 pp 53-61, In Chinese

Cheung YL, Qi YH, Rau R, Stouraitis A (2009) Buy high, sell low: how listed firms price asset transfers in related party transactions. J Bank Financ 33:914-924 
Dhaliwal D, Hogan C, Trezevant R, Wilkins M (2011) Internal control disclosures, monitoring, and the cost of debt. Account Rev 86(4):1131-1156

Doyle JT, Ge WL, McVay S (2007) Accruals quality and internal control over financial reporting. Account Rev 82(5):1141-1170

Fang HX, Jin YN (2011) Can high quality internal control reduce earnings management?-an empirical research based on voluntary internal control audits reporting. Account Res 8:53-60, In Chinese

Feng M, Li C, McVay S (2009) Internal control and management guidance. J Account Econ 48(2-3):190-209

Friedman E, Johnson S, Mitton T (2003) Propping and tunneling. J Comp Econ 31:732-750

Ge WL, McVay S (2005) The disclosure of material weaknesses in internal control after the Sarbanes-Oxley Act. Account Horiz 19(3):137-158

Gordon EA, Henry E, Palia D (2004) Related party transactions: associations with corporate governance and firm value. Working Paper. Rutgers University., No. 4377 of EFA 2004 Maastricht Meetings Paper

Grossman SJ, Hart OD (1986) The costs and benefits of ownership: a theory of vertical and lateral integration. J Polit Econ 94(4):691-719

Jensen M, Meckling W (1976) Theory of the firm: managerial behavior, agency costs, and ownership structure. J Financ Econ 3(4):305-360

Jian M, Wong TJ (2004) Working paper of Nanyang Technological University., which can be found at http://wenku. baidu.com/view/264d797002768e9951e73846.html?from=related\&hasrec $=0$

Jian M, Wong TJ (2010) Propping through related party transactions. Rev Acc Stud 15(1):70-105

Johnson S, La Porta R, Lopez-de-Silanes F, Shleifer A (2000) Tunnelling. Am Econ Rev Pap Proc 90:22-27

Kim JB, Song BY, Zhang L (2011) Internal control weakness and bank loan contracting: evidence from SOX Section 404 disclosures. Account Rev 86(4):1157-1188

Kohlbeck MJ, Mayhew BW (2004) Agency costs, contracting, and related party transactions. Working Paper. University of Wisconsin., http://papers.ssrn.com/sol3/papers.cfm?abstract_id=592582

Lei ACH, Song FM (2011) Connected transactions and firm value: evidence from China-affiliated companies. PacificBasin Financ 19:470-490

Leng J, DING Y (2011) Internal control disclosure and corporate governance: empirical research from Chinese listed companies. Technol Invest 2(4):286-294

Li ZQ, Sun Z, Wang ZW (2004) Tunneling and ownership structure of a firm: evidence from controlling shareholder's embezzlement of listed companies' funds in China. Account Res 12:3-13, In Chinese

Liao L, Fang F (2005) The agency theory of dividend policy: an empirical analysis. Nankai Bus Rev 8(5):55-62, In Chinese

Lin B, Rao J (2009) Why do listed companies disclose the auditor's internal control reports voluntarily? - an empirical study based on signaling theory in China. Account Res 2:45-52, In Chinese

Lin ZG, Zheng J, Wang SZ (2007) Study on relation of internal control and enterprise value: an empirical analysis from Shanghai and Shenzhen stock markets. J Financ Econ 33(4):132-143, In Chinese

Lo AWY, Wong RWK, Firth M (2010) Can corporate governance deter management from manipulating earnings? Evidence from related-party sales transactions in China. J Corp Financ 16(2):225-235

Ma LF, Wang YF, Shen XX (2012) Research on governance effects of China's state-owned companies' party organization - a perspective based on "insiders control". China Ind Econ 8:82-95, In Chinese

Meng Y, Zhang XM (2006) Research on the relationship between earning management by related party transactions and listed company's profit being transferred by related parties. Account Res 4:37-43, In Chinese

National Commission of Fraudulent Financial Reporting (NCFFR) (1987) Report of the National Commission on Fraudulent Financial Reporting: the role of the SEC. October. NCFFR, New York

Ogneva M, Subramanyam KR, Raghunandan K (2007) Internal control weakness and cost of equity: evidence from SOX Section 404 disclosures. Account Rev 82(5):1255-1297

Petrovits C, Shakespeare C, Shih A (2011) The causes and consequences of internal control problems in nonprofit organizations. Account Rev 86(1):325-357

Rao YL, Zhang Y, Peng DF (2008) The impact of excess control of ultimate controlling shareholders on the value of cash holdings. Nankai Bus Rev 11(1):31-38, In Chinese

Ryngaert M, Thomas S (2007) Related party transactions: their origins and wealth effects. SSRN Working Paper., http:// papers.ssin.com/sol3/papers.cfm?abstract_id=970689

Shao J, Liu ZY (2008) Impacts of internal capital market in group on financing constrains of group-affiliations: evidences from Chinese groups. China Account Rev 3:275-288, In Chinese

Singh M, Davidson W (2003) Agency costs, ownership structure and corporate governance mechanisms. J Bank Financ 5:793-816

Skaife HA, Veenman D, Wangerin D (2013) Internal control over financial reporting and managerial rent extraction: evidence from the profitability of insider trading. J Account Econ 55:91-110

Stouraitis A, Cheung SYL, Rau R (2006) Tunneling, propping and expropriation: evidence from connected party transactions in Hong Kong. J Financ Econ 82:343-386

Wang H, Jiang ZH, Hu WM, Zhao LS (2011) Internal control indexes of Chinese listed companies. People's Publishing House, Beijing, In Chinese

Xie J, Wang WY (2010) The efficiency of internal capital markets in Chinese state-owned enterprise groups: an analysis based on double principal-agent relationships. Econ Rev 1:97-104, In Chinese

Yang MZ (2006) Internal capital market, corporate performances and private benefits of control. Account Res 12:61-67, In Chinese

Zhong HY, Ran MS, Wen SX (2010) Government intervention, insider control and investment. Manage World 7:98-108, In Chinese

Zhou XS, Zhang JX (2008) The consequences of related party transactions by controlling shareholders: from an institutional transformation perspective. Contemp Account Rev 1(1):55-71, In Chinese

doi:10.1186/s40527-014-0001-9

Cite this article as: Tong et al: Internal control, related party transactions and corporate value of enterprises directly controlled by Chinese central government. Journal of Chinese Management 2014 1:1. 